\title{
Venturing sustainability: Political lessons from civic engagement and transformative learning in Asia
}

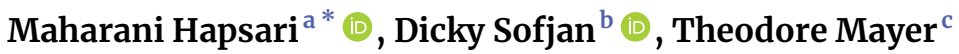 \\ ${ }^{\text {a }}$ Department of International Relations, Faculty of Social and Political Science, Universitas Gadjah Mada, Yogyakarta, \\ Indonesia \\ ${ }^{\mathrm{b}}$ Indonesian Consortium for Religious Studies (ICRS), Universitas Gadjah Mada, Yogyakarta, Indonesia \\ ${ }^{\mathrm{c}}$ School of English for Engaged Social Services (SENS), Institute for Transformative Learning of the International \\ Network of Engaged Buddhism (INEB Institute), Bangkok, Thailand \\ *Corresponding author. Email: ranihps@ugm.ac.id.
}

\section{ABSTRACT}

Current studies on civic engagement offer a critical examination of global civil society's struggles for a sustainable future. The liberal conception of civic engagement sees citizens as voluntary and participatory political subjects in their capacity to achieve a sustainability agenda. In Asia, such conceptions meet with the complex nature of power relations. Using a Gramscian approach and interpretive analysis, this paper draws on the struggles for hegemony, where power relations manifest subtly in state policy, market economy and civil society domains. Learning from the transformative learning experiences of various civil society actors, this study argues that in Asian realities, civic engagement is deeply concerned with the underlying structure of power, forms of negotiation and power dynamics. Political asymmetry is often made implicit by the privileged or uncritically internalized in civic life. There is a need to examine civic engagement as part of "the political", in which antagonism and contradiction are constitutive to social change. Furthermore, civic engagement can, and does, stimulate citizens' deliberate and concerted action against inequality, injustice and indignity.

\section{(C) The authors}

LICENCE This work is licensed under a Creative Commons AttributionNonCommercial 4.0 International License.

DOI 10.30852/sb.2021.1543

\section{RECEIVED 12 May 2021}

PUBLISHED (HTIML) 12 August 2021

PUBLISHED (PDF) 4 October 2021

CITATION Hapsari, M., Sofjan, D., \& Mayer, T. (2021). Venturing sustainability: Political lessons from civic engagement and transformative learning in Asia. APN Science Bulletin, 11(1), 50-56. doi: 10.30852/sb.2021.1543

\section{KEYWORDS}

Civic engagement, transformative learning, sustainability, civil society, Asia, hegemony 


\section{HIGHLIGHTS}

- Transformative learning as a mode of civic engagement is gaining importance in understanding the trajectory of global sustainability transformation.

- The experience of civil society actors in Asia suggests a deeper reflection on the prospect of advancing civic engagement in the struggle for collective will and political leadership.

- Civic engagement involves political struggle to transform power structures that are formative to cultural hegemony.

- Advancing the transformative impacts of civic engagement could address the roots of political exclusions that impede the individual agency.

\section{INTRODUCTION}

The importance of civic engagement as a feature of liberal democratic societies has been well recognized and documented since the initial work of 19th-century British philosopher and political theorist John Stuart Mill's "civic liberalism" (Miller, 2000). Civic engagement includes community service, collective action and political involvement, which are seen in transformative terms since the practices are oriented toward social change (Adler \& Goggin, 2005). It is noteworthy to learn how Asian societies encounter civic engagement as an open democratic project within their unique socioeconomic and cultural context. In pursuing a sustainable future, civic engagement brings together various nationalities, identities, affiliations, and roles of citizens in articulating democratic values and civic cultures as transformative forces. With its long history of communitarian and Confucian traditions, the Asian trajectory of social transformation does not always conform with liberal democratic culture (Hood, 1998). Asia is also home to growth-oriented development models and emerging sustainability technology initiatives. As a site of political struggles by unprivileged individuals and groups, it is a fertile ground for civic engagement and transformative learning projects as politically constituted practices. Critical evaluation of civic engagement in Asia calls for a re-interpretation of being a citizen as part of the larger governing whole. Sustainability desires a systemic transformation to alter the anthropocentric paradigm that drives current planetary metabolism toward a more desirable future that balances intra- and inter-generational justice (WCED, 1987).

Examining civic engagement as part of "the political" (Mouffe, 2005), this paper arises from the dissemination of an international collaborative project that resulted in an edited volume entitled Civic Engagement in Asia: Lessons from Transformative Learning in the Quest for a Sustainable Future (Indrawan, Luzar, Hanna, \& Mayer, 2020). With 24 scholarly works representing civic initiatives from various disciplines, professions, and nationalities, the volume documents how civil society actors working in Asian countries address existential dilemmas while challenging their deeply held assumptions and perspectives in relation to the social world at its broadest through various modes of transformative learning (Mezirow, 1991).

This paper uses Gramscian analysis on civic engagement as a political project in which the struggle for hegemony is integral to social transformation (Gramsci, 1971). Data is sourced from selected chapters in the edited volume, representing cases in Indonesia, Vietnam, Thailand, 
the Philippines and Pakistan. These cases cover the experiences of indigenous people, farmers, workers, local communities, women, teachers, students and religious communities involved in multi-year collaborative knowledge production and civic activisms. The scope of sustainability areas includes human trafficking, urban planning and development, indigenous people's rights, sustainable forestry and sustainable agriculture, social and religious harmony, capacity building and networking support for civil society groups, knowledge creation and sharing, and leadership sharing (Vannarith, Yin, \& Mayer, 2020). Through interpretive analysis, this paper shows how civic engagement practices and transformative learning develop in three domains of hegemonic struggles, namely state policy, the market economy and civil society. It unpacks the structural and cultural context of power imbalances as civil society actors seek to transform inequality, injustices, and indignity that hamper future sustainability. It also presents crucial political issues regarding the everyday and systemic changes towards a collectively desirable sustainability path.

\section{TRANSFORMATIVE LEARNING AS A}

\section{HEGEMONIC PROJECT}

The term transformative learning was introduced by Jack Mezirow (Mezirow, 1978) within the field of education studies and is widely adopted by scholars in various other disciplines. The concept helps to unmask the struggles of unprivileged individuals and social groups when coping with various forms of oppression associated with their everyday social, economic and political dimensions (Schugurensky, 2002). It emphasizes the importance of critical thinking in nurturing individual consciousness, individual behaviour and social transformation against the backdrop of structural and cultural constraints. Therefore, the aspect of self-transformation is as fundamental as realizing the vision to change the social system.

This paper examines transformative learning within the broad constitution of "the political" (Mouffe, 2005) and the contestation of hegemonic leadership (Gramsci, 1971; Thomas, 2009). Hegemony is concerned with how the superstructural elements of civic life-among others, transcendental values, ideology, knowledge production and policy frameworks, along with the expectations of being good citizens-are rationalized. Institutional reforms at the local, national and regional levels signify the response to contradictions that are integral to social change. "The political" denotes the presence of antagonism in the society, whereby differences and conflicts of interest commonly centre on a few dominant groups. The inclusion and exclusion of citizens' antagonism play an important role in shaping the conditions for everyday political contestation. Power relations arrest and constrain antagonism and contradiction to create some form of temporal stability. In such a context, civic engagement can be understood as a way to transform contradictions and antagonisms in society through the discovery of a collective will that is based on a particular ideological leadership and political constellation. In this process, no particular outcome is assured. Rather, sustainability as a focus of civic engagement is ventured, put to the test, set in motion to encounter and work with these myriad contradictions and antagonisms.

The Asian experience presents the dynamics of hegemonic struggles in three domains, namely state policy, the market economy and civil society. In the state domain, transformative learning faces the sedimentation of technical rationalities that often separate bureaucratic or technocratic experts from the rest, which is the case in urban reform in Indonesia (Rifai, 2020). Elite culture defines the distribution of political authority and its privileged knowledge and legitimizes the work of public institutions. The experience of indigenous ethnic communities in Vietnam, the Philippines and Indonesia in reclaiming their rights to land-based livelihoods (Lanh, 2020; Royo, Praputra, Jamisolamin, \& Rochaeni, 2020) discloses continuous negotiation of farmers and agrarian communities with privileged political actors in land-use governance. When 
political accountability is lacking, policy failures and corruption exacerbate unequal redistribution of opportunities at the expense of the non-privileged actors. Policy authority is often associated with dominant interest groups who have the power to counter dissent and critics before they surface. The experience of policy entrepreneurs in Malaysia in mainstreaming conservation policy shows that the scarcity of political resources and the limited space to accommodate a critical stance on government policies leads to self-censorship among civil society actors (Hezri, 2020). In such settings, civic engagement may emerge as a top-down process in which citizens are invited to participate in formulating and implementing government policies. This often relies on leading figures having political openness to embrace diverse civil society aspirations, including those coming from the opposition.

In the market economy domain, the excessive impacts of global capitalism drive various sustainability initiatives. The economic restructuring of local livelihoods needs to take into account two political-economic challenges. The first one is poverty. The case of dealing with human trafficking shows how economically marginalized people are pushed toward risking their lives as they struggle to secure access to the labour market and wealth redistribution beyond national borders (Srakaew \& Tungpuchayakul, 2020). The multiple constraints that overlay the struggle for basic livelihoods often make inclusive public aspirations difficult to realize. The second one is the international pressure toward an autonomous market. In a globalizing economy, market disciplines are strong drivers of shifting citizens' mentality toward becoming economically competitive subjects. Such market disciplines often create pressures on the government to reconcile labour protections and environmental standards with market opening and liberalization. In Thailand, citizen science that works through community monitoring supports pollution-affected communities in industrial sites. This signifies a collective will to limit market externalities that jeopardize the quality of life (Saetang, 2020). Re-embedding social control allows citizens to reclaim the public sphere amidst the infinite pressure of economic growth.

In the civic domain, the mobilization of collective action at the grassroots is a central aspect of transformative learning, one that also represents a critique of the predominant top-down approaches. Such mobilization mostly relies on the power of networked actions, which are fluid in nature. This is also intertwined with the remaking of individual identities. Women's multiple roles as environmental professionals, home managers, policymakers, green entrepreneurs and educators shape the paths toward their environmental leadership in Pakistan when dealing with the climate crisis (Riaz \& Dupar, 2020).

The Asian experience shows that transformative learning transcends the boundaries of territorial sovereignties. The roles of transnational civil society actors in facilitating knowledge production across civic networks are crucial in amplifying the impacts of local struggles. The development of SENS (School of English for Engaged Social Service) by the Bangkok-based International Network of Engaged Buddhists (INEB) shows how such a program can be a site to cultivate human-nature reconnections while also being a cultural bridge to plural civilizations. Through a complex approach, including multiple intelligences, the classroom processes strengthen participants' confidence to unpack the oppressive structures in society that impede their transformative potential (Mayer, 2020). In the civic domain, the role of donor organizations as the interlocutors of knowledge production sites and as players in various aspects of global resource circulation is also well-acknowledged.

Currently, community empowerment and entrepreneurship programs are driven by international development donors, which frequently have to deal with the recurrent problem of economic dependence, which contradicts the normative directions. This is particularly true when the sustainability of these programs is not taken seriously into account in ensuring their longterm outcomes (Lanh, 2020). Furthermore, the 
asymmetric power between donor and beneficiary communities often makes the viewpoints of program beneficiaries less than fully articulated in the decision-making processes.

\section{REIMAGINING CIVIC ENGAGEMENT: THE WAY FORWARD}

The political ecosystem of transformative learning in Asia presents some unique structural constraints to substantive participation and articulation of civil society participation in advancing sustainability agendas. Structural constraints take the form of subtle power mechanisms, which are mostly implicit and are sustained through social inter-subjectivity among actors. Hegemony is embedded in various forms of cultural predominance exacerbated by socio-economic inequalities. The superiority of policymakers, knowledge experts, donors and cultural leaders throughout the process of knowledge production and circulation of resources in the civic networks often legitimizes power disparity through various superstructural means.

Civil society efforts are currently directed toward deepening the impacts of civic engagement projects through transformative actions. The sedimentation of soft politics is becoming a more salient aspect of civil society struggles to challenge inequality, injustice and indignity. Conscious everyday struggles in the form of "infrapolitics" (Scott, 1985) play a strategic role in the Asian context where harmony and cultural prudence have a deep influence on maintaining political obedience and policy compliance. Furthermore, civic-driven sustainability transformation relies heavily on strategies that put forward dialogue, persuasion and empowerment rather than the use of coercive power instruments.

There is a need to re-interpret the meaning of grassroots empowerment, public interchange, partnership and capacity building as prominent instruments of civic engagement. Embracing political realities in the Asian context requires civil society actors to be critical of the potential consequences of power asymmetries in their everyday and normalized forms. An alternative to relations of dominance, civic engagement strategies must be directed to strengthening the political agency of individuals. This is normatively conducted through negotiating what constitutes sustainability agendas that embrace broad-based socio-cultural representations. The entanglement of various sources of knowledge and wisdom presents both opportunity and challenges for civil society actors. Both internal and external critics in transformative learning continuously reshape individual subjectivities and identities. In the context of ecological sustainability, hegemonic struggles need to engage with the "hardware" (the scientific study of ecology and the use of technology), "software" (laws, regulations and policy frameworks imposed by authorities) and "heartware" (individuated, non-tangible and inner dimensions of the drivers of sustainability that are based on the sense of spiritual interconnectedness and a heightened awareness of the role of human beings as "stewards of the earth") (Sofjan, 2020).

More attention needs to be given to the everyday power negotiation through which civil society actors exert their influence and permeate the membranes of hegemonic political institutions. In this context, the intimate connections between civic engagement and citizenship deserve further exploration. Citizenship is concerned with the participation and recognition of citizens as political subjects and their active struggles against injustices within a larger structural context (Hiariej \& Stokke, 2017). The questions of power in the three domains of "the political" provide the momentum for civil society actors to advance their political leverage. Against the backdrop of power disparities, collective actions have developed from the level of the personal to the institutional to the political. Beyond incentivedriven political pragmatism and genuine engagement by respective leaders, more political efforts to transform the subtle dimensions of power are worth exploring. Political change is desirable with the presence of broad-based political leadership that is able to glue the very diverse political positions and nurture cross-sector alliances. 


\section{CONCLUSIONS}

The Asian experience with transformative learning and civic engagement projects provides some important political lessons to further the transition to sustainability. It highlights hegemonic struggles in selected Asian countries and selected sectors. This paper shows that struggles for sustainability in Asia are mostly seen as quite distinct from the liberal democratic view. The dynamic relations of the privileged and underprivileged individuals and groups in the region are subject to continuous political antagonism associated with diverse cultural elements of power asymmetry in respective countries. In venturing sustainability as a concerted effort, plural civil society agendas in Asia involve cooperation and collaboration as well as the presence of fragmentation, disagreement and dialectical political forces. Transformative learning reshapes the individual and public spheres constitutively through interfaces of knowledge and transcendental values. The Asian realities also show that as long as politics continues to be situated mostly within the conventional practice of policymaking, negotiation and building coalitions with state authorities remains a central feature of civil society movements with varying outcomes. Civic engagement initiatives need to embrace political contestation and antagonism that construct policymaking, even as we recognize and appreciate the ongoing productive work of civil society actors within all three domains and at many levels of the social order.

\section{ACKNOWLEDGEMENT}

The authors would like to acknowledge the financial support from the Asia-Pacific Network for Global Change Research (APN), Project reference: CBA2018-05SY-Indrawan.

\section{REFERENCES}

Adler, R., \& Goggin, J. (2005). What do we mean by "civic engagement. Journal of transformative education, 3(3), 236-253. doi:10.1177/1541344605276792

Gramsci, A. (1971). Selections from the prison notebooks. Lawrence \& Wishart.
Hezri, A.A. (2020). Policy entrepreneurship for sustainable development in Malaysia: A reflection. In M., Indrawan, J., Luzar, Hanna, H., \& Mayer, T. (Eds.), Civic Engagement in Asia: Lessons from Transformative Learning in the Quest for a Sustainable Future (pp. 269276). Yayasan Pustaka Obor Indonesia.

Hiariej, E., \& Stokke, K. (Eds.). (2017). Politics of citizenship in Indonesia. Yayasan Pustaka Obor Indonesia.

Hood, S.J. (1998). The myth of Asian-style Democracy. Asian Survey, 38(9), 853-866. doi:10.2307/2645622

Indrawan, M., Luzar, J., Hanna, H., \& Mayer, T. (2020). Civic Engagement in Asia: Lessons from Transformative Learning in the Quest for a Sustainable Future. Yayasan Pustaka Obor Indonesia.

Lanh, T.T. (2020). Building livelihood sovereignty for the Mekong Region. In M., Indrawan, J., Luzar, Hanna, H., \& Mayer, T. (Eds.), Civic Engagement in Asia: Lessons from Transformative Learning in the Quest for a Sustainable Future (pp. 1-16). Yayasan Pustaka Obor Indonesia.

Mayer, T. (2020). In these troubled times, could every classroom become a site of transformation? The story of the SENS Program. In M., Indrawan, J., Luzar, Hanna, H., \& Mayer, T. (Eds.), Civic Engagement in Asia: Lessons from Transformative Learning in the Quest for a Sustainable Future (pp. 227-245). Yayasan Pustaka Obor Indonesia.

Mezirow, J. (1978). Perspective transformation. Adult Education Quartlerly, 28, 100-110. doi:10.1177/074171367802800202

Mezirow, J. (1991). Transformative dimensions of adult learning. San Francisco: Jossey-Bass.

Miller, D.E. (2000). John Stuart Mill's civic liberalism. History of Political Thought, 21(1), 88-113.

Mouffe, C. (2005). On the Political. Abingdon, Oxon: Routledge.

Riaz, A., \& Dupar, M. (2020). Female-driven climate and environmental action: Champions from Pakistan. In M., Indrawan, J., Luzar, Hanna, H., \& Mayer, T. (Eds.), Civic Engagement in Asia: Lessons from Transformative Learning in the Quest for a Sustainable Future (pp. 197211). Yayasan Pustaka Obor Indonesia.

Rifai, A. (2020). Urban reform in Indonesia. In M., Indrawan, J., Luzar, Hanna, H., \& Mayer, T. (Eds.), Civic Engagement in Asia: Lessons from Transformative Learning in the Quest for a Sustainable Future (pp. 135143). Yayasan Pustaka Obor Indonesia.

Royo, A.G., Praputra, A.V., Jamisolamin, J., \& Rochaeni, N. (2020). Building recognition for the resource rights of indigenous peoples and local communities. In $\mathrm{M}$., 
Indrawan, J., Luzar, Hanna, H., \& Mayer, T. (Eds.), Civic Engagement in Asia: Lessons from Transformative Learning in the Quest for a Sustainable Future (pp. 1728). Yayasan Pustaka Obor Indonesia.

Saetang, P. (2020). The role of citizen science in policy advocacy and building just and ecologically sustainable communities in Thailand. In M., Indrawan, J., Luzar, Hanna, H., \& Mayer, T. (Eds.), Civic Engagement in Asia: Lessons from Transformative Learning in the Quest for a Sustainable Future (pp. 57-74). Yayasan Pustaka Obor Indonesia.

Schugurensky, D. (2002). Transformative learning and transformative politics: The pedagogical dimension of participatory democracy and social action. In O'Sullivan, E., Morrell, A., \& O'Connor, M.A. (Eds.), Expanding the Boundaries of Transformative Learning: Essays on Theory and Praxis (pp. 59-76). Palgrave Macmillan.

Scott, J.C. (1985). Weapons of the weak: Everyday forms of peasant resistance. New Haven, CT: Yale University Press.

Sofjan, D. (2020). The heartware of ecological sustainability in the Asian context. In M., Indrawan, J., Luzar,
Hanna, H., \& Mayer, T. (Eds.), Civic Engagement in Asia: Lessons from Transformative Learning in the Quest for a Sustainable Future (pp. 29-44). Yayasan Pustaka Obor Indonesia.

Srakaew, S., \& Tungpuchayakul, P. (2020). Fighting modern slavery in Southeast Asian Waters. In M., Indrawan, J., Luzar, Hanna, H., \& Mayer, T. (Eds.), Civic Engagement in Asia: Lessons from Transformative Learning in the Quest for a Sustainable Future (pp. 187196). Yayasan Pustaka Obor Indonesia.

Thomas, P. (2009). Gramsci and the Political: From the state as 'metaphysical event' to hegemony as 'philosophical fact. Radical philosophy, 153, 27-36.

Vannarith, C., Yin, M.M., \& Mayer, T. (2020). Reflections on civic engagement and key issues raised in this volume. In M., Indrawan, J., Luzar, Hanna, H., \& Mayer, T. (Eds.), Civic Engagement in Asia: Lessons from Transformative Learning in the Quest for a Sustainable Future (pp. 293-307). Yayasan Pustaka Obor Indonesia. WCED (1987). Report of the World Commission on Environment and Development: Our Common Future. 